\title{
Strategy for Biodiversity Conservation Efforts in Wasur National Park of Merauke in Merauke Regency
}

\author{
Samel W Ririhena ${ }^{1}$, Marthen Nahumury ${ }^{2}$, David Oscar Simatupang ${ }^{3}$ \\ ${ }^{1}$ Dapertement of Economic and Busniness, Faculty of Economic and Business, Musamus University, Merauke - Indonesia \\ ${ }^{2}$ Dapertement of Economic and Busniness, Faculty of Economic and Business, Musamus University, Merauke - Indonesia \\ ${ }^{3}$ Dapertement of Agibusiness, Faculty of Agriculture, Musamus University, Merauke - Indonesia
}

\begin{abstract}
Development of Wasur National Park can drive the economy, improve local and national images, improve public welfare through purchase of local product, open jobs and increase regional income. Tourism sector will be an effective means. The research type was descriptive by using qualitative approach by analyzing SWOT strategy, analysis diagram and determination of strategic initiative priority. There were four results. The alternative SWOT strategy referred to diversification or integration strategy diagram at quadrant IV : S-O (strength and opportunity) Strategy, inventory of potentials of natural and human resources to support research and education as well as culture; S-T (strength and threat) Strategy, Having fauna tourism potential and local village areas to support community economy for environmental conservation.; W-O (weakness and opportunity) Strategy Improvement of human resources of local village; W-T (weakness and threat) Strategy Requirement for work group guidance for local community in the conservation area to facilitate supervision and utilization of human resources in the conservation area. The strategic priority to start was cooperation with related party to improve very low range of control of related institutions. Use strategy to reduce carbon emissions conservation area and neighboring areas conservation city merauke particularly affected direct against urban development
\end{abstract}

Keywords: Wasur National Park, SWOT, Alternative Strategic Priority.

\section{INTRODUCTION}

Merauke Regency is a regency in Indonesia located in Southern Papua Province. Its forest is $95.3 \%$ of its total area, located east-most of the country. The regency is bordered by Papua New Guinea. Its area is $45.071 \mathrm{Km} 2$ and it has rich natural resources with $\pm 40,5$ million Ha of forest. It has a National Park which is the habitat of many types of organisms. Many variations of existing population form diversity which makes the ecosystem in the National Park a natural heritage which must be protected and conserved. Biodiversity consists of flora (plants) and fauna (animals) living across Wasur National Park.

Wasur National Park is a vast tropical forest with an area of $4.138 \mathrm{~km} 2$. As a wildlife reserve and nature preserve, it has the largest number of endemic animals and plants in Papua. There are rare animals, such as bird of paradise, cassowary, kangaroo, arwana, etc. Furthermore, some lakes and marshes offer natural beauty. The potentials in developing Wasur National Park have bright future in the future and will provide attraction for visitors, whether those from local communities or from other regions who visit Merauke Regency. Wasur National Park is also known as Serengeti of Irian. Serengeti is the name of a national park in Tanzania, Australia. Meanwhile, "Wasur" comes from the word "Waisol" which in Marind language means park. Wasur National Park is a national park in Merauke Regency-Papua. Wasur National Park is established as a national park based on the decree of the Minister of Forestry number: 448/Menhut-VI/1990, dated 6 March 1990. The area of Wasur National Park is 413,810 ha. Flora and fauna potentials in Wasur National Park are massive. This park is established by the Minister of Forestry in 1997 from Wasur Wildlife Reserve and Rawa Biru Nature Preserve. Wasur National Park is one of 50 National Parks in Indonesia managed as UPT (Technical Implementation Unit) since 1997. TNW was previously managed by Natural Resources Conservation Sub-Center of Irian Jaya II C.q. Natural Resources Conservation Sub-section of Merauke and WWF ID. 0105 Merauke.

Therefore, Wasur National Park should be developed to be able to drive the economy, improve local and national images, improve public welfare through purchase of local product, open jobs and increase regional income. Tourism sector will be an effective means to distribute income to the society evenly from those with high income to those with low income from other regions or countries.

*Corresponding author: ririhena@unmus.ac.id 


\section{Research Method}

The research type was descriptive by using qualitative approach by analyzing SWOT strategy, analysis diagram and determination of strategic initiative priority. Descriptive analysis aims to describe someone which is currently happening (event) factually, systematically, and accurately on the causes of a certain symptom. The research location was Wasur National Park, Merauke District, Merauke Regency, which has potential tourism site. The data collection technique was secondary data. Secondary data was collected from various reports and other references relevant with the research problem. Books, reports was studied (library research) in the Department of Tourism and Department of Regional Income of Merauke Regency.

\section{RESULT AND DISCUSSION}

\section{Potential of Wasur Park Area}

Wasur Park has the natural attractions of plants, animals or natural ecosystem, as well as interesting geological formation. It has sufficient area to ensure the conservation of potential functions and attractions to be used for tourism and outdoor recreation. The condition of the surrounding environment supports efforts of natural tourism development. The conservatory function of nature tourism park is protecting the life support system of the area around the TWA area. The academic function of nature tourism park is teaching about nature and developing science. The tourism function of nature tourism park is becoming tourist destination and outdoor recreation are supported by natural beauty and the ecosystem of the area.

\subsection{Wasur National Park Development Strategy}

Table 1. Analysis of External Factors of Wasur National Park

\subsection{Management and utilization of Nature Tourism Park}

Nature Tourism Park has the following benefits: Nature tourism and recreation, research and development, education and cultural support activities. The management of Wasur National Park uses Zonation system based on: SK. Dirjen PKA No:15/Kpts/DJ V/2001, dated 6 February 2001: Core Zone : Area \pm $127.590 \mathrm{Ha}$, consisting of 2 (two) with the following perimeters : North $\pm 82 \mathrm{Km}$, South $\pm 184 \mathrm{Km}$ with total perimeter \pm 266 . Forest Zone : Area $\pm 211.320 \mathrm{Ha}$, consisting of 2 (two) with the following perimeters: North $\pm 229,2 \mathrm{Km}$, South $\pm 316,8 \mathrm{Km}$ with total perimeter $\pm 546 \mathrm{Km}$ Intensive Utilization Zone: Area \pm $56.100 \mathrm{Ha}$ with total perimeter: $\pm 380 \mathrm{Km}$. Residential Zone : Area \pm 18.800 Ha with total perimeter $: \pm 73,6 \mathrm{Km}$ consisting of : Kondo Village $\pm 20 \mathrm{Km}$, Tomerau \pm 18 $\mathrm{Km}$, Wasur $\pm 13,4 \mathrm{Km}$, Rawa Biru (Yereu) $\pm 20,4 \mathrm{Km}$, Yanggandur $\pm 15 \mathrm{Km}$, Sota $\pm 18 \mathrm{Km}$, Bokrum $\pm 25,8$ $\mathrm{Km}$, Tambat $\pm 23,8 \mathrm{Km}$ and Soa $\pm 19,2 \mathrm{Km}$.

The tourism potential of biological resources in Wasur National Park include; 1). Melaleuca Dominant Forest; 2). Melaleuca - Eucalyptus Co-dominant Forest; 3). Rare Forest; 4). Beach Forest; 5. Seasonal Forest ;6). Riparian Riparian; 7). Mangrove Forest; 8). Savannah Forest; 9). Grassland Forest; 10). Marsh Grassland. Beside biological resources potentials in Wasur National Park, there are animal tourism potentials such as; 1). Mammals; 2). Birds); 3). Fishes; 4). Insects; 5). Reptiles and Amphibians.

\subsubsection{External Factor Analysis}

\begin{tabular}{|l|l|l|l|l|}
\hline No & External Environmental Factor & Weight & Rating & Score \\
\hline
\end{tabular}




\begin{tabular}{|l|l|l|l|l|}
\hline \multicolumn{2}{|l|}{ Threat } & & & -0.18 \\
\hline 1 & Threat on conservation area by economic activity of local communities & 0.09 & -2 & \\
\hline 2 & Traditional hunting which causes biological damage. & 0.15 & -1 & -0.15 \\
\hline 3 & Customary land rights & 0.15 & -1 & -0.15 \\
\hline 4 & Existing road between towns & 0.06 & -2 & -0.12 \\
\hline Score Weight & 1 & -2 & -2 \\
\hline \multicolumn{2}{|l|}{ Total Score } & & & $-2,6$ \\
\hline \multicolumn{2}{|l|}{ Total weight (Opportunity + Threat) } & $-0,74$ \\
\hline
\end{tabular}

\subsubsection{Internal Factor Analysis}

Table 2. Analysis of Internal Factors of Wasur National Park

\begin{tabular}{|c|c|c|c|c|}
\hline No & Internal Environmental Factor & Weight & Rating & Score \\
\hline \multicolumn{5}{|c|}{ Opportunity } \\
\hline 1 & $\begin{array}{l}\text { Protected by Law (Decision of Minister of Forestry: } \\
\text { 448/Menhut-VI/1990, dated } 6 \text { Marsh 1990) as conservation } \\
\text { area }\end{array}$ & 0.15 & 4 & 0.6 \\
\hline 2 & Flora and fauna diversity & 0.18 & 4 & 0.72 \\
\hline 3 & Traditional or local communities & 0.05 & 3 & 0.15 \\
\hline 4 & Adequate infrastructures & 0.07 & 2 & 0.14 \\
\hline 5 & Easy road access & 0.07 & 3 & 0.21 \\
\hline 6 & Potential with district or city for the need for clean water & 0.08 & 2 & 0.16 \\
\hline \multicolumn{4}{|c|}{ Total weight } & 1,98 \\
\hline \multicolumn{5}{|c|}{ Weakness } \\
\hline 1 & Inadequate facilities & 0.08 & -2 & -0.16 \\
\hline 2 & Nomadic communities & 0.15 & -4 & -0.6 \\
\hline 3 & $\begin{array}{l}\text { Education and training on conservation which aren't } \\
\text { intensive and optimal }\end{array}$ & 0.1 & -3 & -0.36 \\
\hline 4 & $\begin{array}{l}\text { Biological and fauna potentials which haven't been } \\
\text { inventoried }\end{array}$ & 0.07 & -2 & -0.14 \\
\hline \multicolumn{4}{|c|}{ Total Score } & $-1,26$ \\
\hline \multicolumn{4}{|c|}{ Total weight (Opportunity + Weakness) } & 0,72 \\
\hline
\end{tabular}

\subsubsection{SWOT Analysis Diagram}




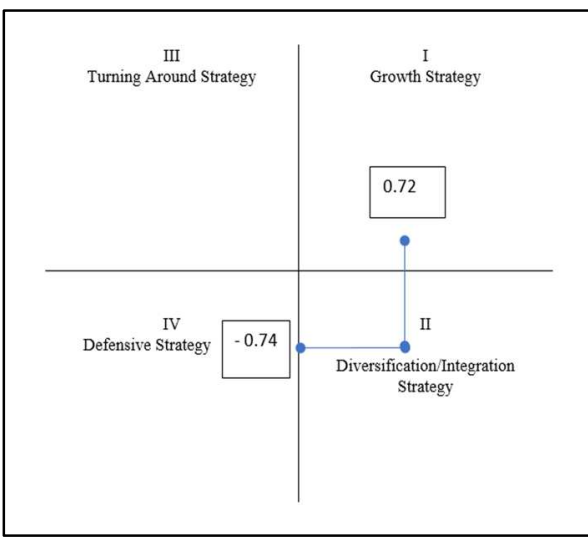

Fig 1. SWOT Analysis Diagram

\subsection{Strategy Determination by SWOT Matrix}

\begin{tabular}{|l|l|l|}
\hline External & $\begin{array}{l}\text { Strengths } \\
\text { 1)Protected by Law (Decision of } \\
\text { Minister of Forestry: 448/Menhut- } \\
\text { VI/1990, dated 6 March 1990) as } \\
\text { conservation area } \\
\text { 2)Flora and fauna diversity } \\
\text { 3)Traditional or local communities } \\
\text { 4)Adequate infrastructure } \\
\text { 5)Easy road access } \\
\text { 6)Potential with district or city for the } \\
\text { need for clean water }\end{array}$ & $\begin{array}{l}\text { Weakness } \\
\text { 3) Education and training on } \\
\text { conservation which aren't intensive } \\
\text { and optimal } \\
\text { 4)Biological and fauna potentials } \\
\text { which haven't been inventoried }\end{array}$ \\
\end{tabular}




\begin{tabular}{|c|c|c|}
\hline $\begin{array}{l}\text { Opportunity } \\
\text { 1)Having tourism potential of RI and } \\
\text { PNG border } \\
\text { 2)Having potentials of educational } \\
\text { tourism and research site } \\
\text { 3)Having orchid cultivation } \\
\text { 3)Having support from related } \\
\text { institutions, including Wasur Park } \\
\text { Conservation Center, department of } \\
\text { forestry. } \\
\text { 4)Having Bomi sai office which is } \\
\text { conservation and research center }\end{array}$ & $\begin{array}{l}\text { 1)Support for research development } \\
\text { and education, as well as culture } \\
\text { 2)Becoming role model for ecosystem } \\
\text { balance and economic fulfillment of } \\
\text { local community. } \\
\text { 3)Inventory of flora and fauna } \\
\text { 4)Training on environmentally } \\
\text { friendly management of nature and } \\
\text { education on biodiversity and fauna. }\end{array}$ & $\begin{array}{l}\text { 1)Improvement of human resources of } \\
\text { local villages } \\
\text { 2)Research development and } \\
\text { education to explore potentials in } \\
\text { Wasur park area as a nature } \\
\text { conservation }\end{array}$ \\
\hline $\begin{array}{l}\text { Threats } \\
\text { 1)Threat on conservation area by } \\
\text { economic activities of local } \\
\text { communities } \\
\text { 2)Traditional hunting which causes } \\
\text { biological damage. } \\
\text { 3)Rights on customary lands } \\
\text { 4)Existing road between towns }\end{array}$ & $\begin{array}{l}\text { 1)Protecting fauna tourism potential } \\
\text { 2)Local village communities which } \\
\text { encourages economic activities of the } \\
\text { communities for environmental } \\
\text { conservation. }\end{array}$ & $\begin{array}{l}\text { 1)Guidance for work groups for local } \\
\text { communities living in the } \\
\text { conservation area } \\
\text { 2)Cooperation with related party } \\
\text { reduces very low range of control of } \\
\text { related institutions. }\end{array}$ \\
\hline
\end{tabular}

\subsubsection{Analysis}

\section{S-O (strength and opportunity) Strategy}

Inventorying potentials of natural and human resources can support research and education, thus being a role model of ecosystem balance and economic fulfillment of local communities. Development of flora and fauna can be opportunity for the area, having positive impact on educational tourism which prioritizes training on environmentally friendly management and nature and education on biodiversity and fauna.

S-T (strength and threat) Strategy

It has fauna tourism potentials of having 34 species of 80 mammal species identified, 114 protected species of birds (Aves), wet land which has aquatic potentials of being the home of 39 types of fish of 72 existing types and 25 types of protected reptiles and amphibians, local village communities which encourage economic activities for environmental conservation.

\section{W-O (weakness and opportunity) Strategy}

Improvement of human resources of local villages to work with the government to conserve the nature of the conservation area and improvement of the resources of the Department of Forestry, Wasur Park Center, university in research and education to explore the potentials in Wasur park area as a nature conservation.

W-T (Weakness and threat) Strategy

Requiring guidance for work groups for local communities living in the conservation area, thus facilitating supervising and utilization of natural resources in the conservation area without limiting the economic needs of local villages. Therefore, cooperation with related parties become stronger in protecting the sustainability of the conservation area from irresponsible people and reduce the very low range of control of related institutions.

\footnotetext{
*Corresponding author: ririhena@unmus.ac.id
} 


\subsection{Alternative Determination of Strategic Initiative Priority}

\begin{tabular}{|c|c|c|c|c|c|}
\hline No & Strategic Initiative & Weight & Rating & Score & $\begin{array}{l}\text { Strategic } \\
\text { Initiative } \\
\text { Priority }\end{array}$ \\
\hline 1 & research and education as well as culture & 0.1 & 2 & 0.2 & 7 \\
\hline 2 & $\begin{array}{l}\text { Being role model for ecosystem balance and economic fulfillment of local } \\
\text { community. }\end{array}$ & 0.08 & 3 & 0.24 & 5 \\
\hline 3 & Flora and fauna development & 0.03 & 2 & 0.06 & 10 \\
\hline 4 & $\begin{array}{l}\text { Training on environmentally friendly management of nature and education } \\
\text { on biodiversity and fauna. }\end{array}$ & 0.13 & 4 & 0.52 & 2 \\
\hline 5 & Improvement of human resources of local villages & 0.07 & 2 & 0.14 & 8 \\
\hline 6 & $\begin{array}{l}\text { Research development and education to explore potentials in Wasur park } \\
\text { area as a nature conservation }\end{array}$ & 0.06 & 3 & 0.18 & 6 \\
\hline 7 & Protecting fauna tourism potential & 0.09 & 1 & 0.09 & 9 \\
\hline 8 & $\begin{array}{l}\text { Local village communities which encourages economic activities of the } \\
\text { communities for environmental conservation. }\end{array}$ & 0.11 & 3 & 0.33 & 4 \\
\hline 9 & $\begin{array}{l}\text { Guidance for work groups for local communities living in the conservation } \\
\text { area }\end{array}$ & 0.14 & 3 & 0.42 & 3 \\
\hline 10 & $\begin{array}{l}\text { Cooperation with related party reduces very low range of control of related } \\
\text { institutions. }\end{array}$ & 0.19 & 4 & 0.76 & 1 \\
\hline & Total weight & 1,00 & & & \\
\hline
\end{tabular}

\section{Conclusion}

1. There are four Alternative SWOT strategies which refer to the diagram of diversification or integration strategy in quadrant IV :

a. S-O (Strength and opportunity) Strategy Inventorying the potentials of natural and human resources to support research development and education, as well as culture

b. S-T (Strength and threat) Strategy Having fauna tourism potential and local village communities which encourage the economic activities of the communities for environmental conservation.

c. W-O (Weakness and opportunity) Strategy Improvement of human resources of local villages d. W-T (Weakness and threat) Strategy Requirement for guidance for work groups for local communities living in the conservation area to facilitate supervision and utilization of natural resources in the conservation area

2. Strategic priority to start the strategy is cooperation with related parties to reduce very low range of control of the related institutions. Use strategy to reduce carbon emissions conservation area and neighboring areas conservation city merauke particularly affected direct against urban development

\section{References}

1 Hunger dan Wheelen. 2003. dalam Fredi Rangkuti Analisis SWOT Teknik Membedah Kasus Bisnis. PT. Gramedia Pustaka Utama, Jakarta.

2 Suryawan Ady, Christita Margareta, Yuliantoro. Potensi Strategi Pengembangan Taman Hutan Raya Gunung Tumpa Manado, Sulawesi Utara dalam Upaya Konservasi Keanekaragaman Subkawasan Wallace, Pros Sem Nas Masy Biodiv Indon Volume 1, Nomor 4, Juli 2015

3 Tunggal, Amin, Widjaja. 1994. Pengantar Manajemen Strategik. Harvarindo, Jakarta.WWF 